\title{
Creative Thinking -Perception of Teachers in Relation to its Importance
}

\author{
Dr. Shqipe Haxhihyseni \\ "Aleksander Moisiu" University \\ Durres, Albania \\ shqipeshyti@yahoo.com
}

\begin{abstract}
Creative thinking is an important element in the process of education and social development, but little treat in teaching practice. The purpose of this paper is to highlight the factors that encourage creativity of the child and the factors that constrain it, mainly in the educational environment, thinking that the way the teacher perceives creative mind plays an important factor in the development or diminishing its. Drawing on contemporary literature review on the topic provided the theoretical foundations that support the development of creative thinking and through surveys of teachers will emerge problems with the perception of teachers about creative thinking and its importance in the development of students. Results of the study show that the perception of teachers for the form of thinking that should encourage the students is an important factor to help students increase their chances to get in the right way at teaching knowledge and use it productively creative in their future.
\end{abstract}

Keywords: creative thinking, perception of teachers, incentive thinking

\section{Introduction}

My 20 years experience of teaching has led me study creative thinking and the way it is perceived, because along this period my observation is that there is little attention paid to it; and teachers work are focused on knowledge acquisition and have neglected creative thinking. Similar, in the Albanian literature (pedagogical) it is spoken less about creative thinking whereas the time we live in requires creative thinking, just as stated in the curricular framework presented by IZHA (Education Development Institute). Acqusition and elaboration of knowledge autonomously, creatively, responsibility are of high importance in order to learn, as well to decision making and problem solving. Keeping in mind the complexity of society and of today economy based on knowledge, information management is a key competence in the XXIst century. Students need not only to acquire that information but to develop the necessary skills to thinking critically, creatively and interactively.

\section{Literature Review}

Michael Mumford suggested: "Over the course of the last decade, however, we seem to have reached a general agreement that creativity involves the production of novel, useful products" (Mumford, 2003, p. 110). Creativity can also be defined "as the process of producing something that is both original and worthwhile" or "characterized by originality and expressiveness and imagination". What generates might come in different forms for various subjects or areas.

\section{Importance of creative thinking}

Critical and creative thinking are the keys to work and economic prosperity in the twenty-first century. There is a long-term trend away from routine-oriented work, which requires people to do the same things every day, and toward creativityoriented jobs that ask people to engage in analysis and to make judgments. The creative class includes people whose work is to create new forms (for example, writers, engineers, and designers) and people who work in a wide range of knowledgeintensive industries that ask them to make critical and creative decisions about specific problems in their fields. According to Patel in web page: Think "Successful universities in the twenty-first century will be those that educate graduates who contribute to a critical and creative workforce". Therefore the curriculum of a specific school whether elementary, 
secondary, or college, should have it as a must to include creative and critical thinking along classroom activities and have them interrelated in between. Thus decision making and problem solving are 2 most important of the many areas that teachers may help foster students creativity because in general students are more motivated when they have to do a task where they should put their own efforts which don't go in vain but that seems really valuable to their practical life.

There are many methods on how to increase creativity. Psychologists, Synetics, Mathematicians and many other researchers have developed ideas and programs and variants on how to foster and increase creative thinking.

Much of the thinking done in formal education stresses out the skills of teaching students understand claims, the answer, create a logical argument, eliminate the incorrect paths and focus on the correct one. However, there is another kind of thinking, one that focuses on exploring ideas, generating possibilities, looking for many right answers rather than just one. Both of these kinds of thinking are vital to a successful working life, yet the latter one tends to be ignored until after college.

Creativity: It's been maligned, neglected, and misunderstood. But it's finally coming into its own(Azzam, 2009). Creativity is being introduced as the crucial skill of our century in order to problem solving. However, creativity is more than just ideas on the spot, instead it is a kind of assessment, because every thing that you are facing with needs to be assessed first then solved. So, creativity process is deeper than just thinking about the issue.

But why it is given so much emphasis to creative thinking just right now?

The answer is that the world has transformed so much that people need to think really quickly about their lives and about everything they do. People face a lot of different, strange, quite ridiculous challenges that they must have a creative mind to deal with all this otherwise the failure is behind the window. Information comes to us in an advanced way and everyday there are huge changes which are not visible to the eye but they impact greatly on each individual's life. Eras of the history have not been the same not one equal to another, therefore every period has developed something important at the time needed. This is also the case of creative thinking. It is needed now and for the future of our children. They must be informed about all these changes and must learn and confront them in a creative way, with their imagination. And this happens only if teachers do foster a creative thinking and help their little minds and behaviors imagine and create in order to solve and make decisions for their future and for their present life and world.

Can creativity be taught?

The creativity expert Sir Ken Robinson believes that it is possible to teach creativity, although some people say they can't. This comes from the fact that they do not understand it themselves and it is very difficult to teach something you dont understand first.

"But there are actually two ways of thinking about teaching creativity. First of all, we can teach generic skills of creative thinking, just in the way we can teach people to read, write, and do math. Some basic skills can free up the way people approach problems-skills of divergent thinking, for example, which encourage creativity through the use of analogies, metaphors, and visual thinking."(cited above)

\section{Developing creativity}

'We really need to stop considering thinking as simply 'intelligence in action' and think of it as a skill that can be developed by everyone.' (Edward De Bono, 1982)

According to De Bono (1982) fostering creativity in an effective way we must develop some techniques that are specific for thinking because our brain is not designed for that purpose as the first purpose of its function and it is not capable of creating great things or ideas.

Over the years, De Bono and other writers have promoted the view that creative thinking is something that can be developed by anyone and they have formulated a wide range of practical techniques to develop thinking skills. 


\section{Methodology}

\section{Participants and Setting}

This study aims to determine whether the perception of teachers on creativity matches classroom practices they apply. The sample included 32 teachers of five elementary schools of the city of Elbasan, which were chosen based on their availability and convenience to submit first round of surveys, respectively. Teachers participating in the questionnaire had different levels of grade, including teachers of the program English as a Second Language (ESL) and teachers of special education

\section{Variables}

The survey contained questions about classroom daily practices and classroom procedures, methods of grading and expectations of teacher. The first two involved classroom material location, choices of students and methods of instruction. Method of grading and expectation of teacher concentrated on what the teacher looks for in the works of students and their classroom participation. The survey was created by researcher, based on literature and adjusted for the purpose of this study. Its validity and reliability is not known.

\section{Procedures of Data Collection}

Prior to the beginning of the project it was obtained a written permission from the public school system coordinator. Survey participants were volunteers who had consented since the first round surveys and were informed on confidentiality of their responses linked to personal identification.

The second and third round of surveys were sent to teachers electronically, by email, thus they managed completion time on their own. Their individual responses were then collected into aggregated data.

\section{Instrument}

The study instrument of research integrated three consecutive completed surveys by the participants. Surveys were created based on literature research that linked with creative thinking activities, its qualities and its fostering. The first two surveys contained ideas or activities regarding grading methods, practices and procedures of classroom and expectations of teachers. Survey questions were rated on a Likert-scale 0-10, where participants had to choose their agreement degree in each given statement by selecting numbers from 0 which showed Never to 10 which showed Always. The first survey measured the frequency of occurred classroom activities and it showed approximately equal numbers of activities that impeded and fostered creativity ideas or thoughts. The second survey measured the specific activities that teachers considered as appropriate to help creativity. The third survey measured what was each teacher's belief about creative thinking in general with the children being present in the classroom environment. This survey was designed to have Likertscale questions and short answer spaces combination in case of any additional comments.

\section{Procedure}

The first survey drew activities which promoted and hindered creative thinking in the classroom. These activities were rated by the teacher according to their frequency in the classroom on a 1-10 scale.

The last two surveys were sent electronically to the provided email addresses at the same time. Also, reminders were sent each day after the first delivery. The second survey contained the same activities as the first survey but here teachers were asked to rate activities based on their personal belief on each activity potential to help and foster creative thinking. Afterwards, the two surveys were compared in order to analyze the relationship of beliefs of teachers on these activities and the time they spent in the classroom to foster them in students mind and behavior.

The third survey contained questions asking teachers to give opinions and again beliefs to be used for the fostering of classroom creativity. This last survey drew some feedback on participants perception based on practices in the classroom. 


\section{Results}

\section{Demographics}

All respondents were female teachers. Table 1. The percentage of respondents from each participating grade level and from each participating school.

\begin{tabular}{|l|l|l|l|}
\hline School & Percentage & Grade & percentage \\
\hline School 1 & 18.75 & ESL Teacher & 12.50 \\
\hline School 2 & 12.50 & Special education & 18.75 \\
\hline School 3 & 18.75 & Grade 1-2 & 25.00 \\
\hline School 4 & 25.00 & Grade 3-4 & 25.00 \\
\hline School 5 & 25.00 & Grade 5 & 18.75 \\
\hline
\end{tabular}

\section{Participation}

The first survey delivered to the 32 respondents was paper based which regarded the frequency of different classroom activities. Between the first survey and the second survey there was a $52 \%$ completion decrease of surveys, meaning 18 total of completed responses. Between the second survey and the third survey there was even more decrease in completion by $75 \%$, thus 14 total of completed responses.

\section{Data Analysis}

For the purpose of data analysis, questions of the first and second surveys were divided into categories, where the first category included activities of teaching that foster creativity and the second category the activities of teaching that do not foster it.

For data analysis purposes, the questions presented in Surveys 1 and 2 were divided into the following two dichotomous categories: (a) teaching activities that foster creativity and (b) teaching activities that do not foster creativity. Responses were divided into 5 categories from 0-1 strongly disagree, 2-3 disagree, 4-6 neutral, 7-8 agree, 9-10 strongly agree. Activities of the classroom that foster creativity make $15 \%$ (x questions) of all classroom activities.

Activities that do not foster creativity make $40 \%$ of occurred activities often within the respondents' classrooms.

10 of the questions are believed to be on activities of the classroom fostering creative thinking. 4 questions were in fact that didn't have high scores included process of instruction and classroom activities of competitions. 8 questions indicated fostering activities on creativity. ( see the table below)

Table 3. Survey Questions.

\begin{tabular}{|c|c|}
\hline Foster creativity questions & Do not foster creativity questions \\
\hline $\begin{array}{l}\text { - I involve multiple senses in my lessons. } \\
\text { - I relate the content material in my class to } \\
\text { real-world experiences. } \\
\text { - Grades in my class are mostly based on the } \\
\text { student having the correct answer not the } \\
\text { correct process. } \\
\text { - } \quad \text { Ccompetition takes place in my classroom. } \\
\text { - I allow children to choose their own projects } \\
\text { for demonstrating their knowledge. }\end{array}$ & $\begin{array}{l}\text { I keep my art materials (markers, glue, } \\
\text { crayons, scissors, etc.) locked up and not } \\
\text { available to the children. } \\
\text { I involve my students in a brainstorming } \\
\text { process before starting a new project or } \\
\text { concept. } \\
\text { I focus on topics in my classroom that the } \\
\text { children already understand. }\end{array}$ \\
\hline
\end{tabular}




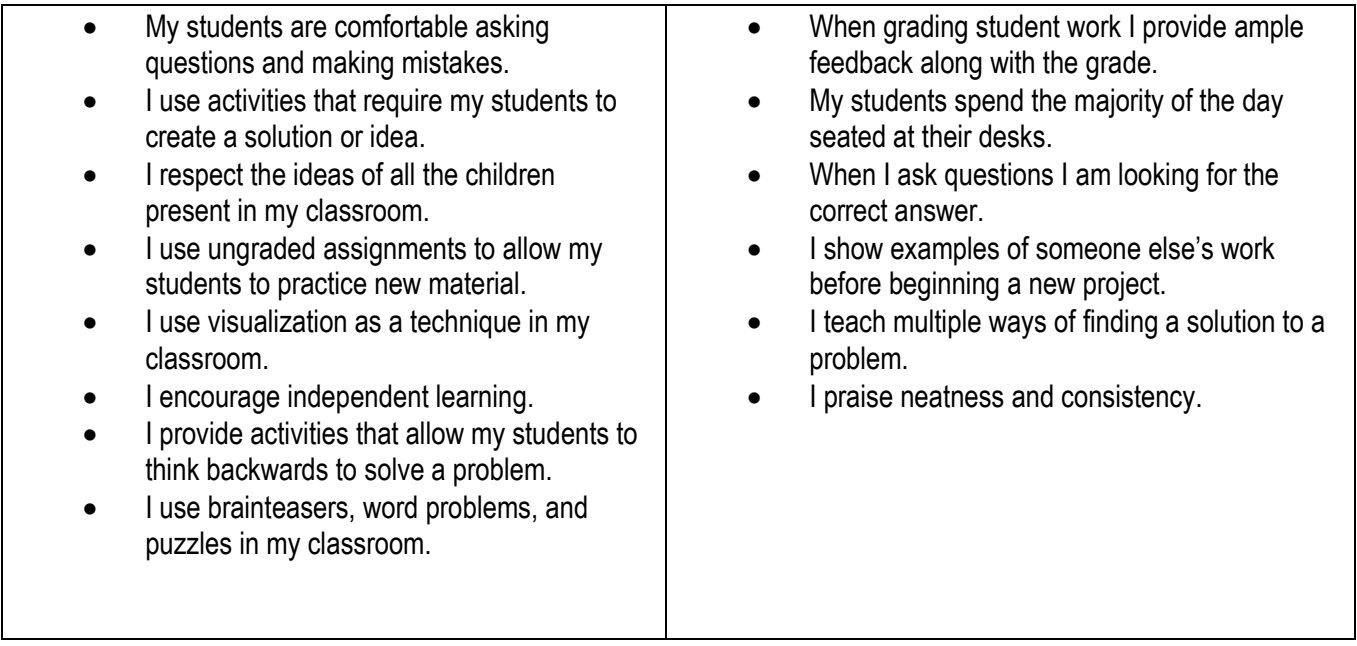

The third survey examined own classroom perceptions and practices of teaching. 4 out of 6 quesitons demonstrated teachers' agreement that they foster creative thinking in their particuar classroom.

The third survey included some additional space for comments in order to improve understanding of the resereach on perceptions. Half of the comments responses included the agree category on fostering creative thinking in writing as an easy area to incorporate creativitiy. $20 \%$ agreed on providing chances for creativity within the activities of the classroom in wiriting because social studies offer less oppportunities because of the curriculum plan. The third survey included question on whether teachers planned their activities for the intetnion to foster creative thinking. The respondents' answers were mostly negative. $34 \%$ of the respondents on commenting believe they incorporate creativity with hobbies of students and others refer to flexibility and spontaneity as features of creative thinking. Findings suggest that teachers sometimes seek answers from their students as different ideas although they may not be correct as responses. $75 \%$ of the teachers do not perceive their students as creative and that their creativity is very different.

As a conclusion, findings suggest that teachers understand and know creativity and activities related to foster it. The most part of it incorporate $30 \%$ classroom practices with creative thinking activities in the classroom.

\section{Discussion}

The findings of research project suggest that teachers in Elbasan schools consider creative thinking very important but their activities in the classroom do not match and align with creativity. According to the first survey the activities that hinder creativity occur more often in the classroom. The second survey indicates that teachers know which activities foster creative thinking.

This study aimed to analyse if there is a match between perception of creativity and clasroom activities to develop the necessary skills for it. Findings suggest that although teachers know and undestand creativity importance they don't do much to sperate form their daily routines on content masterization instead of focusing on activities to foster creativity.

Other findings of survey 1 and 2 include misconception some of the teachers have of creativity. On the question about the grading method teachers focused on the correct response not on the process of it. This is somehting that suggest that traditional methods or other factors like standard tests are yet stressed more in the classroom activities. 


\section{Conclusion}

In conclusion respondets capture the meaning of creativity as an important capability nowadays therefore the importance of it to be fostered in the classroom, nontheless teachers state that they are not doing much to develop it. They simply take into consideration free ideas of students as a means to develop creativity but not developing it through activities planned beforehand. Albanian schools, although they have in their curricula the development of creatie thinking and critical thinking and place much emphasis, they still continue to focus on masterization of material content rather than mastering it through creativity, imagination and critical thinking as the most and very useful skills to be fostered for the future of their students.

\section{Limitations of this Research}

As the data from this study are analyzed there were many factors to be taken into consideration such as the sample especially for the first and second survey. It was difficult to contact and receive permission from the admisnitrators of some schools for their teahcers to participate in the surveys.

Another limitation is that there were no test to provide a reliable and valid administred surveys because survey were self reflceted responses and there may have been bias form the part of the participants who voluntreed in the surveys, thus the conclusions cannot be generalized for all schools in the city of Elbasan.

\section{Implications}

Accoridng to results, in general teachers know the perception of creativity and understand hwereas others misconcept it or have difficulty implementing it in the clasrrom activities. Mostly they focus on masterizaiton of content of material instead of fostering material creative thinking. Although teachers are aware of the great importance of creativity skills in the future, they are incapable or don't know how to interact its skills with other activities in the classroom.

\section{Recommendations for Future Research}

Studies on such topic should include more and a larger representative sample, involving more schools, levels of grade, districts and areas for findings generalized to a larger population.

According to the findings of this study there is no a significant correlation between teachers' perception of what forsters creativity and their classroom practice activities. For better and more accurate results it would have been interesting to use classroom case studies and data from observations made in the classroom to be added to the data from self-reflection survey responses.

This study included a great amount of items which might have cause the participants to respond less in the following surveys due to time of completion they might have taken.

Interesting and of great significance would have been to include data from administrators about their perception of creative thinking and also to see if they supported teachers in develoiping such skills as well the study should have included both administrators and teachers educational background and their particular trainings about classroom creativity fostering in order to examine the impact of these variables.

\section{References}

[1] Azzam, M. A, http://www.ascd.org/publications/educational-leadership/sept09/vol67/num01/Why-CreativityNow\%C2\%A2-A-Conversation-with-Sir-Ken-Robinson.aspx

[2] De Bono. E,(1982) De Bono's thinking course, BBC Books

[3] Harris, J. (1993). Introducing Writing. London: Penguin Books Ltd. 
[4] Mumford, D. (2003). Where have we been, where are we going? Taking stock in creativity research. Creativity

[5] Patel.M,http://qep.ncsu.edu/why-is-critical-and-creative-thinking-important-to-student-success/

[6] Research Journal, 15, 107-120. http://dx.doi.org/10.1207/S15326934CRJ152\&3_01 